\title{
Privately Held or Publicly Owned? Large Shareholders and Corporate Control
}

\author{
Amjad Toukan \\ Department of Economics, Lebanese American University, Beirut, Lebanon \\ Email: amjad.toukan@lau.edu.lb \\ Received 2 March 2014; revised 2 April 2014; accepted 25 April 2014 \\ Copyright (C) 2014 by author and Scientific Research Publishing Inc. \\ This work is licensed under the Creative Commons Attribution International License (CC BY). \\ http://creativecommons.org/licenses/by/4.0/ \\ c) (†) Open Access
}

\begin{abstract}
This paper examines the decision to go public in the presence of large and dispersed shareholders. The decision to go public and the shape of the ownership structure itself depend on the particular combination of concentrated and dispersed ownership that maximizes the initial owners' wealth. Owners/managers and large shareholders exert costly efforts to increase their share of the value of the public firm. The respective shares and the listing decision are affected by the efficiency of the judiciary and law enforcement system.
\end{abstract}

\section{Keywords}

Ownership Structure, Corporate Governance, Agency Costs, Monitoring, Managerial Conflict, Legal Protection, Investor Protection

\section{Introduction}

Economists since Adam Smith have warned that a separation between ownership and management opens the possibility of insider abuse (Enron and WorldCom scandals are recent examples of insider abuse). A clear disadvantage of the separation between ownership and management is the principal-agent problem that occurs between shareholders and managers and the agency costs incurred as a result of it. In our analysis we will examine the decision to go public in the presence of both large and dispersed shareholders and we will focus on the agency costs that are incurred due to 1) the monitoring costs incurred by large shareholder's in trying to keep managers' objectives aligned with their own in maximizing the value of the firm and 2) managers' furthering their own interest rather than maximizing the value of the firm.

According to La Porta, et al. [1], monitoring by shareholders includes more than just measuring or observing the behavior of the managers. It includes efforts on the part of the shareholders to "control" the behavior of the managers through budget restrictions, compensation policies, operating rules, and other methods. The way 
managers further their own interest (specifically expropriate shareholders) can take a variety of forms as well. In some instances, the managers simply steal the profits. In other instances, managers sell the output, the assets, or the additional securities in the firm they control to another firm they own at below market prices. Such transfer pricing, asset stripping, and investor dilution, though often legal, have largely the same effect as theft. In still other instances, expropriation takes the form of diversion of corporate opportunities from the firm, installing possibly unqualified family members in managerial positions, or overpaying executives.

Our paper joins the literature on corporate governance in the area of investor protection. Castillo and Skaperdas [2] examine how the legal protection of outside shareholders and the appropriative costs that they induce influence the incentives for private firms to go public. They model the conflict between the owners/managers and outside shareholders as a contest to the secure part of the value of the public firm. Their findings indicate that owners are more likely to go public when outside shareholders are better protected. In the case of going public, Castillo and Skaperdas obtain a non-monotone relationship between the legal protection of outside shareholders and the size of the ownership share retained by the owners/managers. Building on their work, our paper considers not only the decision to go public, but also the initial firm's optimizing ownership structure in terms of the composition of concentrated (or large) and dispersed (or small) shareholders.

We present a model of entrepreneurs who consider the possibility of taking their company public. When absenting an outright buyer, the entrepreneurs choose among two options: they can sell a share of the company in the stock market and create a firm run publicly held by the original founders or they can keep the company private. In going public, the entrepreneurs choose the future ownership structure in a manner that maximizes their expected payoff. In contrast to much of the existing literature, we make the distinction between large and dispersed shareholders and examine the differences in their incentives to monitor the managers. Dispersed shareholders, having a high opportunity cost of monitoring the managers, free ride on the efforts of large shareholders ${ }^{1}$. Suppose that the initial owners' factor in the differential monitoring effects of large and dispersed shareholders represents a point of departure of the analysis. This point of departure provides some insight into the large crosssectional differences across countries in the ownership concentration in publicly traded firms and the possible origins of these differences. According to La Porta et al. [3], the patterns of ownership vary across countries with the highest concentration of ownership found in the French-civil-law countries and the lowest found in a sample of East Asian countries where company law has been significantly influenced by the United States.

So who are the large shareholders and what characterizes their ownership share in public firms? According to Shleifer and Vishny [4], large shareholdings are extremely widespread and very substantial where present. In a sample of 456 of the Fortune 500 companies, the authors find that 354 have at least one shareholder owning at least 5 percent of the firm. In only 15 cases, the largest shareholder owns less than 3 percent of the firm. The average holding of the largest shareholder among the 456 firms is 15.4 percent. In their sample, large shareholders are families represented on boards of directors (149 cases), pension and profit-sharing plans (90 cases), financial firms such as banks, insurance companies, or investment funds (117 cases) and the final category consists of firms and family holding companies with large stakes who do not have board seats (100 cases).

In contrast to dispersed shareholders, large shareholders receive a discount on the price of their shares equal in value to the cost of the efforts they exert in monitoring the managers. Jensen and Meckling [5], argue that prospective large shareholders will realize that the owners/managers' interests will diverge somewhat from theirs; hence the price that they will pay for shares will reflect the monitoring costs and the effect of the divergence between the manager's interest and theirs.

Similar to Burkart and Panunzi [7], we assume that large shareholders and managers are distinct parties. Being a Board Member or even its Chairman is quite different from being the CEO of the firm, and their interests are likely to differ. We depart from others in assuming that there is no collusion between large shareholders and managers in expropriating dispersed shareholders. Rather we assume that the interests of the large and the dispersed shareholders are perfectly congruent.

Our analysis takes a game theoretic approach, modeling the conflict between managers and shareholders as a

\footnotetext{
${ }^{1}$ Shleifer and Vishny [4] show that in a corporation with many small owners, it may not pay any one of them to monitor the performance of the management. They build on Grossman and Hart [6] argument that opposite to what is often suggested, the free rider problem cannot be avoided by the use of the takeover bid mechanism. Outsiders without a share in a diffusely held firm would never take over a diffusely held firm in order to improve it. The reason is that outsiders' improvement plan would be understood by atomistic incumbent shareholders and they will demand the value of the improvement in return for their shares or else they stay on. If the outsider can gain only on the shares they already own (which are few if any) but have to pay all the monitoring and takeover costs, the deal may not be worth their while. For the same reason, small shareholders do not have a big enough stake in the firm to absorb the costs of watching the management.
} 
contest (see Skaperdas [8]). According to Anderton [9], one of the necessary building blocks of a unifying micro-theory of conflict economics is the contest success function (CSF), which specifies how the appropriative efforts of agents lead to an appropriative outcome. To date, two families of CSFs have been developed. In one family, the conflict outcome depends on the ratio of fighting efforts; in the other family it depends upon the difference of fighting efforts as in Hirshleifer [10]. Our main analysis incorporates the first family of the CSF where the ratio of the efforts expended by the owners/managers and large shareholders determines how much is appropriated by each as in Clark and Riis [11]. As a robustness check we compare the results obtained in our main analysis with the results obtained by the use of the other family of the CSF where in this second case the difference of the efforts expended by the owners/managers and large shareholders determines how much is appropriated by each as in Skaperdas and Vaidya [12].

Results predicted by the use of both types of CSFs are consistent with the existing literature for example, Lopez-de-Silanes, Shleifer and Vishny [13], Shleifer and Wolfenzon [14] and Pagano and Röell [15] show that the better the legal protection of outside shareholders the more valuable the public firm and the more likely that the owners of a private firm will take their company public. Consistent with the results of Lopez-de-Silanes, Shleifer and Vishny [3], Shleifer and Wolfenzon [14] and Burkart, Panunzi and Shleifer [16], we also obtain a negative relationship between the concentration of ownership shares in public companies and the legal protection of outside shareholders. As the legal protection of outside shareholders improves, entrepreneurs choose to decrease their share of ownership in the public firm while increasing that of dispersed shareholders. The share of ownership sold to large shareholders is non-monotonic in the legal protection of outside shareholders.

The paper is organized as follows. Section 2 outlines the model. Section 3 solves the model utilizing Tullock's contest success function (see Tullock [17]), examines the owner's decision to go public and analyzes the effect of a change in the efficiency of the legal system on the shape of the firm's ownership structure. Section 4 solves the model utilizing Skaperdas and Vaidya's contest success function (see Skaperdas and Vaidya [12]), examines the owner's decision to go public and analyzes the effect of a change in the efficiency of the legal system on the shape of the firm's ownership structure. Section 5 concludes.

\section{The Model}

We consider a three-stage model, where in the first stage the firm is privately owned-that is, by its original founders. In stage 1 , the owners decide whether to take their company public. We assume that, if they go public, they will stay on as managers of the public firm due to their special expertise in running the firm. A decision to go public incorporates what fraction $\beta$ of the shares to sell to large shareholders, what fraction $\alpha$ to keep, what fraction $1-\alpha-\beta$ to sell to dispersed shareholders and what fraction $\gamma$ of the equity sales proceeds to reinvest back into the public firm. Dispersed shareholders exert no effort in protecting their investment in the public firm but rather they free ride on the efforts of large shareholders in monitoring the managers. The sequences of actions in this game are depicted in Figure 1.

In stage three of the game, owners/managers and large shareholders compete for corporate control. We assume that owners/managers are forward-looking whereby they choose the optimal ownership structure in stage two of the game in a manner that maximizes their expected payoff in stage three.

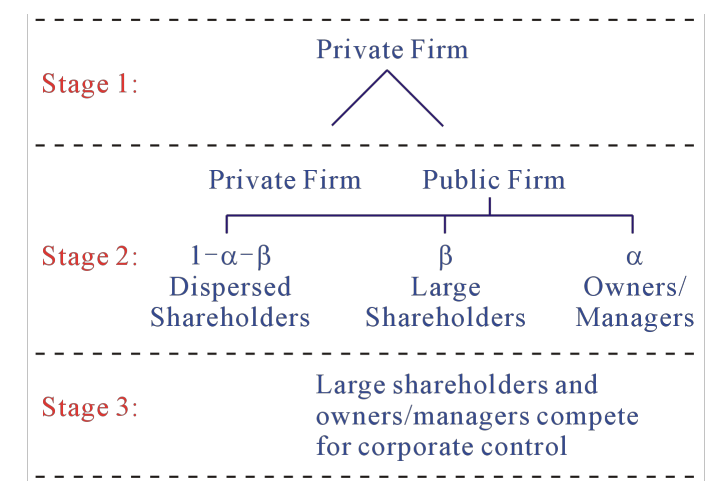

Figure 1. The sequence of actions in the decision to go public. 
According to Zingales [18], entrepreneurs must weigh the benefits and the costs of going public before deciding to proceed with an Initial Public Offering (IPO). On the costs side, there are the registration and underwriting costs, the underpricing costs (Ritter [19]), the annual disclosure costs, and the agency problems generated by a separation between ownership and management (Jensen and Meckling [5]). On the benefit side, there are benefits of diversification, the possibility of equity financing beyond the initial entrepreneurs' limited wealth, less costly access to the capital markets, an increased liquidity of the company's shares, and some outside monitoring (Holmstrom and Tirole [20]). In our analysis we assume that the gross value of the public firm is given by $V_{P}(\gamma S)$, which is increasing in the amount of equity sales proceeds $(\gamma S)$ reinvested back into the firm: $V_{P}^{\prime}(\gamma S) \geq 0 . V_{f}$ represents the market value of the private firm and is exogenously determined.

The share of the gross value of the public firm expropriated by the owners/managers is a function, $q\left(e_{m}, e_{l s}\right)$, depending on two kinds of effort: $e_{m}$ representing costly efforts exerted by the owners/managers to expropriate part of the value of the public firm, and $e_{l s}$ representing costly efforts exerted by large shareholders to protect their investment in the firm. Assume, $q\left(e_{m}, e_{l s}\right) \in[0,1]$, which is increasing in $e_{m}$ and decreasing in $e_{l s}$. $1-q\left(e_{m}, e_{l s}\right)$ represents the share received by shareholders (including the owners/managers who keep a share of the firm).

Examples of the efforts exerted by large shareholders in monitoring the managers include auditing, formal control systems, budget restrictions, and the establishment of incentive compensation systems which serve to identify the manager's interests more closely with those of shareholders. Examples of the efforts exerted by the managers in expropriating shareholders include managers paying themselves large salaries and generous perquisites, diverting company resources for corporate empire building and for private benefits, and stealing business opportunities from the company.

The payoff to the owners/managers, net of the costs of their efforts $e_{m}$, depends on the share of the firm they can expropriate $q\left(e_{m}, e_{l s}\right)$ and the share they never relinquished $\alpha$ as follows:

$$
V_{m}\left(e_{m}, e_{l s} ; \alpha, \beta, \gamma S\right)=\left(q\left(e_{m}, e_{l s}\right)+\alpha\left(1-q\left(e_{m}, e_{l s}\right)\right)\right) V_{P}(\gamma S)-e_{m}
$$

The net value to large shareholders who own a fraction, $\beta$, of the firm is given by:

$$
V_{l s}\left(e_{m}, e_{l s} ; \alpha, \beta, \gamma S\right)=\beta\left(1-q\left(e_{m}, e_{l s}\right)\right) V_{P}(\gamma S)-e_{l s}
$$

The net value to dispersed shareholders is then given as the residual value of the public ownership of the firm $(1-\alpha-\beta)$ :

$$
V_{d s}\left(e_{m}, e_{l s} ; \alpha, \beta, \gamma S\right)=(1-\alpha-\beta)\left(1-q\left(e_{m}, e_{l s}\right)\right) V_{P}(\gamma S)
$$

Recall that dispersed shareholders, by definition are free-riders, and thus exert no effort in the competition for corporate control $\left(e_{d s}=0\right)$. The net value to shareholders who own a fraction, $(1-\alpha)$, of the firm is given by:

$$
V_{s}\left(e_{m}, e_{l s} ; \alpha, \beta, \gamma S\right)=(1-\alpha)\left(1-q\left(e_{m}, e_{l s}\right)\right) V_{P}(\gamma S)-e_{l s}
$$

\subsection{Third Stage Choice of Efforts}

Large shareholders and owners/managers choose their equilibrium efforts simultaneously and in a manner that maximizes their total payoffs in stage three of the game. Given values of the owners/managers share in the public firm $(\alpha)$, large shareholders share $(\beta)$ and the value of the public firm to both large and dispersed shareholders $(S)$ the owners/managers choose $e_{m}$ to maximize their payoff $V_{m}$ shown in (1). Similarly large shareholders choose $e_{l s}$ to maximize their payoff $V_{l s}$ shown in (2). Assuming interior optima, $e_{m}^{*}$ and $e_{l s}^{*}$, these solutions are defined implicitly by the respective first order conditions as functions of $\alpha, \beta$ and $\gamma S$. Substituting the equilibrium efforts $e_{m}^{*}$ and $e_{l s}^{*}$ into Equations (1) and (4) above we get the equilibrium payoffs to the owners/managers $V_{m}^{*}$ and to shareholders $V_{S}^{*}$. Because $e_{m}^{*}$ and $e_{l s}^{*}$ depend on $\alpha, \beta$ and $\gamma S, V_{m}^{*}$ and $V_{S}^{*}$ are also functions of $\alpha, \beta$ and $\gamma S$.

\subsection{Expected Payoff to Owners/Managers}

The expected payoff to the owners/managers from taking their private firm public $\left(V_{O}^{*}\right)$ equals the equilibrium payoff to owners/managers $\left(V_{m}^{*}\right)$ plus the amount that owners/managers $(1-\gamma) S$ decide to keep from the 
equity sales proceeds.

$$
V_{o}^{*}(\alpha, \beta, S)=V_{m}^{*}(\alpha, \beta, \gamma S)+(1-\gamma) S
$$

The amount $(S)$ that shareholders are willing to pay for their share in the public firm should equal the equilibrium payoff to shareholders $\left(V_{S}^{*}\right)$ or the amount that shareholders expect to receive from their share of ownership in the public firm, so that:

$$
S=V_{s}^{*}(\alpha, \beta, \gamma S)=V_{d s}^{*}(\alpha, \beta, \gamma S)+V_{l s}^{*}(\alpha, \beta, \gamma S)
$$

Due to their added efforts in monitoring the management, large shareholders pay a lower price for the same amount of shares than dispersed shareholders (Shleifer and Vishny [4]). In our model large shareholders receive a discount on the price of their shares equal in value to the cost of the efforts they exert in monitoring the managers.

\subsection{Choosing the Optimal Ownership Structure to Owners/Managers}

Owners/managers choose the proportion of shares to sell to large shareholders $(\beta)$, the proportion to keep $(\alpha)$, which together imply the proportion to sell to dispersed shareholders $(1-\alpha-\beta)$, and the fraction $(1-\gamma)$ of the equity sales proceeds to keep that maximize their expected payoff from taking their company public. Specifically, they solve:

$$
\operatorname{Max}_{\alpha, \beta, \gamma}\left(V_{m}^{*}(\alpha, \beta, \gamma S)+(1-\gamma) V_{s}^{*}(\alpha, \beta, \gamma)\right)
$$

To proceed we consider specific functional forms for the contest success function $q\left(e_{m}, e_{l s}\right)$ and for the gross value of the public firm $V_{P}(\gamma S)$. We will utilize two different types of contest success functions (Clark and Riis [11] and Skaperdas and Vaidya [12]) in the contest between managers and shareholders as illustrated in Sections 3 and 4 below.

\section{Equilibrium Choices Where the Partners Compete in an Asymmetric Contest for Control}

In the third stage of the game, the competition between large shareholders and owners/managers is modeled as a contest in which the participants exert costly efforts to increase their probability of winning part of the value of the public firm (Clark and Riis [11]). What is unique about this specification is that it supposes that, even when the two partners expend identical efforts, one of the two partners will enjoy a greater share of the value of the firm.

$$
q\left(e_{m}, e_{l s}\right)=\frac{(1-\theta) e_{m}^{\sigma}}{(1-\theta) e_{m}^{\sigma}+\theta e_{l s}^{\sigma}}, \text { where } \sigma>0
$$

The parameter $\sigma$ represents the effectiveness of the conflict technology or the degree to which greater appropriative effort translates into conflict success. $\theta$ represents the efficiency of the judiciary and law enforcement system in a country and it varies between 0 and 1 . An increase in $\theta$ towards 1 would indicate stronger law enforcement or a more efficient legal system which would favor shareholders. Conversely a movement of $\theta$ toward 0, would indicate weaker law enforcement or a less efficient legal system. Suppose, for example, that $\theta<1 / 2$, if both parties devoted an equal amount of effort to the contest, the outcome would favor the original owners/managers.

Large shareholders and owners/managers choose their equilibrium efforts simultaneously and in a manner that maximizes their total payoffs in stage three of the game. Given values of the owners/managers share in the public firm $(\alpha)$, large shareholders share $(\beta)$ and the value of the public firm to both large and dispersed shareholders $(S)$ we solve for the owners/managers equilibrium efforts by differentiating Equation (1) above with respect to $e_{m}$ and setting it equal to zero:

$$
\frac{\sigma \theta(1-\theta) e_{l s}^{\sigma^{*}} e_{m}^{\sigma-1^{*}}}{\left((1-\theta) e_{m}^{\sigma^{*}}+\theta e_{l s}^{\sigma^{*}}\right)^{2}}(1-\alpha) V_{P}(\gamma S)=1
$$

In order to solve for large shareholders' equilibrium efforts, we differentiate Equation (3) above with respect 
to $e_{l s}$ and we set it equal to zero:

$$
\frac{\sigma \theta(1-\theta) e_{m}^{\sigma^{*}} e_{l s}^{\sigma-1^{*}}}{\left((1-\theta) e_{m}^{\sigma^{*}}+\theta e_{l s}^{\sigma^{*}}\right)^{2}} \beta V_{P}(\gamma S)=1
$$

Combining Equations (20) and (21) above, we get:

$$
e_{l s}^{*}=\frac{\beta}{1-\alpha} e_{m}^{*}
$$

Plugging in Equation (11) into Equations (9) and (10) above, we can solve for the owners'/managers' and large shareholders equilibrium efforts as given by Equations (12) and (13) below:

$$
\begin{gathered}
e_{m}^{*}=\frac{\sigma \theta(1-\theta)(1-\alpha)\left(\frac{\beta}{1-\alpha}\right)^{\sigma}}{\left[(1-\theta)+\theta\left(\frac{\beta}{1-\alpha}\right)^{\sigma}\right]^{2}} V_{P}(\gamma S) \\
e_{l s}^{*}=\left(\frac{\beta}{1-\alpha}\right)^{\frac{\sigma \theta(1-\theta)(1-\alpha)\left(\frac{\beta}{1-\alpha}\right)^{\sigma}}{\left[(1-\theta)+\theta\left(\frac{\beta}{1-\alpha}\right)^{\sigma}\right]^{2}}} V_{P}(\gamma S)
\end{gathered}
$$

Substituting (12) and (13) into (1) and (2) above we get the equilibrium payoffs to the owners/managers and to shareholders respectively:

$$
\begin{aligned}
V_{m}^{*}(\alpha, \beta, \gamma S) & =\frac{[(1-\theta)+\alpha \theta \beta]\left[(1-\theta)+\theta\left(\frac{\beta}{1-\alpha}\right)^{\sigma}\right]-\sigma \theta(1-\theta)(1-\alpha)\left(\frac{\beta}{1-\alpha}\right)^{\sigma}}{\left[(1-\theta)+\theta\left(\frac{\beta}{1-\alpha}\right)^{\sigma}\right]^{2}} V_{p}(\gamma S) \\
V_{s}^{*}(\alpha, \beta, \gamma S) & =\frac{(1-\alpha) \theta \beta\left[(1-\theta)+\theta\left(\frac{\beta}{1-\alpha}\right)^{\sigma}\right]-\sigma \theta(1-\theta)(1-\alpha)\left(\frac{\beta}{1-\alpha}\right)^{\sigma+1}}{\left[(1-\theta)+\theta\left(\frac{\beta}{1-\alpha}\right)^{\sigma}\right]_{p}} V_{p}(\gamma S)
\end{aligned}
$$

\subsection{Choosing the Optimal Ownership Structure to Owners/Managers}

We now turn to the owners/managers choice of ownership structure. This choice factors in the effects the choices will have on $e_{l s}^{*}$ and $e_{m}^{*}$ and thus on $V_{s}^{*}$ and $V_{m}^{*}$. Owners/managers solve:

$$
\operatorname{Max}_{\alpha, \beta, \gamma}\left(V_{m}^{*}(\alpha, \beta, \gamma S)+(1-\gamma) V_{s}^{*}(\alpha, \beta, \gamma)\right)
$$

Due to the complexity in solving the maximization problem above, we will illustrate by an example as shown below:

Example: We assume that that the value of the public firm is determined through a Cobb-Douglas-like form:

$$
V_{p}(\gamma S)=K(\gamma S)^{\psi} \text { where } K>0 \text { and } \psi \text { is between } 0 \text { and } 1
$$

We assume that $\psi$, a measure of the productivity of a public firm, increases with improvements in the efficiency of the judiciary and law enforcement system. According to Hall and Jones [21], differences in levels of economic success across countries are driven primarily by the institutions and government policies (or infrastructure) that frame the economic environment in which people produce and transact. Societies with secure 
physical and intellectual property rights that encourage production are successful. Societies in which the economic environment encourages the diversion of output instead of its production produce much less output per worker. Diversion encompasses a wide range of activities, including theft, corruption, litigation, and expropriation. In our analysis we will allow for increases in $\psi$ that are commensurate with the improvements in the efficiency of the judiciary and law enforcement system. Plugging in (17) into (15) above, we get:

$$
S=V_{s}^{*}(\alpha, \beta, \gamma S)=K^{\frac{1}{1-\psi}} \gamma^{\frac{\psi}{1-\psi}}\left[\frac{(1-\alpha) \theta \beta\left[(1-\theta)+\theta\left(\frac{\beta}{1-\alpha}\right)^{\sigma}\right]-\sigma \theta(1-\theta)(1-\alpha)\left(\frac{\beta}{1-\alpha}\right)^{\sigma+1}}{\left[(1-\theta)+\theta\left(\frac{\beta}{1-\alpha}\right)^{\sigma}\right]^{\frac{1}{1-\psi}}}\right.
$$

To determine the optimal share to sell to large shareholders $\beta^{*}$, the optimal share to keep $\alpha^{*}$ and the optimal share to sell to dispersed shareholders $(1-\alpha-\beta)^{*}$, we plug in (17) and (18) into the maximization problem (16) above. Due to the difficulty in obtaining an explicit solution, I have solved the maximization problem using a numerical investigation as shown in Figure 2 and Figure 3 attached. Numerical solution results show the optimal ownership structure that maximizes the expected payoff to owners/managers for the different values of $\theta$ (efficiency of the judiciary and law enforcement system) and are discussed in the sections below.

\subsection{Analysis of Figure 2 Below}

Numerical solution results show that owners/managers get a higher return from investing an additional dollar in the public firm than they would from retaining it (except for investing in the public firm, we assume that the owners/managers earn zero return on their money), so they reinvest the full amount of the equity sale proceeds back into the public firm $\left(\gamma^{*}=1\right)$.

In our model, we have assumed that the legal protection of outside shareholders complements the efforts exerted by large shareholders in monitoring the managers, so as the efficiency of the judiciary and law enforcement system improves $(\theta \uparrow)$, equity valuation by outside shareholders increase and the value of public firms increase. Results obtained from our numerical solution are consistent with the existing literature as we show that as the efficiency of the judiciary and law enforcement system improves $(\theta \uparrow)$, the optimal value to the owners/ managers from taking their firm public increases and the likelihood that entrepreneurs will take their privately held firms public increases. An example with $V_{f}{ }^{2}$ as the market value of the private firm and $V_{O}^{*}$ being the optimal value to the owners/managers from taking their firm public is shown in Figure 2 attached.

\subsection{Analysis of Figure 3 Below}

In deciding to take their company public, three sources of value contribute to the owners/managers payoff: expropriating part of the value of the public firm; retaining part of the proceeds received from selling equity; and the value received from being shareholders.

In a forward looking game, the owners/managers will decide on the optimal ownership structure in stage two of the game in a manner that maximizes their expected payoff from taking their firm public in stage three. The owners/managers weigh the costs and benefits of expropriation of outside investors that comes with control. Such private benefits of control, as described by Jensen and Meckling [5], do come at the expense of profits accruing to the outside investors (including the owners/managers who keep a share of the firm). In legal regimes with weak investor protection (low values of $\theta$ ), the owners/managers can steal a firm's profits perfectly efficiently and no rational outsider would finance such a firm. In such legal regimes, the cost of raising capital to entrepreneurs is high and the family firm emerges as the value maximizing outcome where the original owners retain both ownership and control.

As investor protection improves, the expropriation technology becomes less efficient, the owners/managers expropriate less, and their private benefits of control diminish. Entrepreneurs then obtain outside finance on better terms. In addition to the legal protection of outside shareholders, the presence of large shareholders restricts managers' excessive spending and is in the best interest of dispersed shareholders. Pagano and Röell [15] show

\footnotetext{
${ }^{2}$ The value of the private firm is exogenously determined in our model.
} 


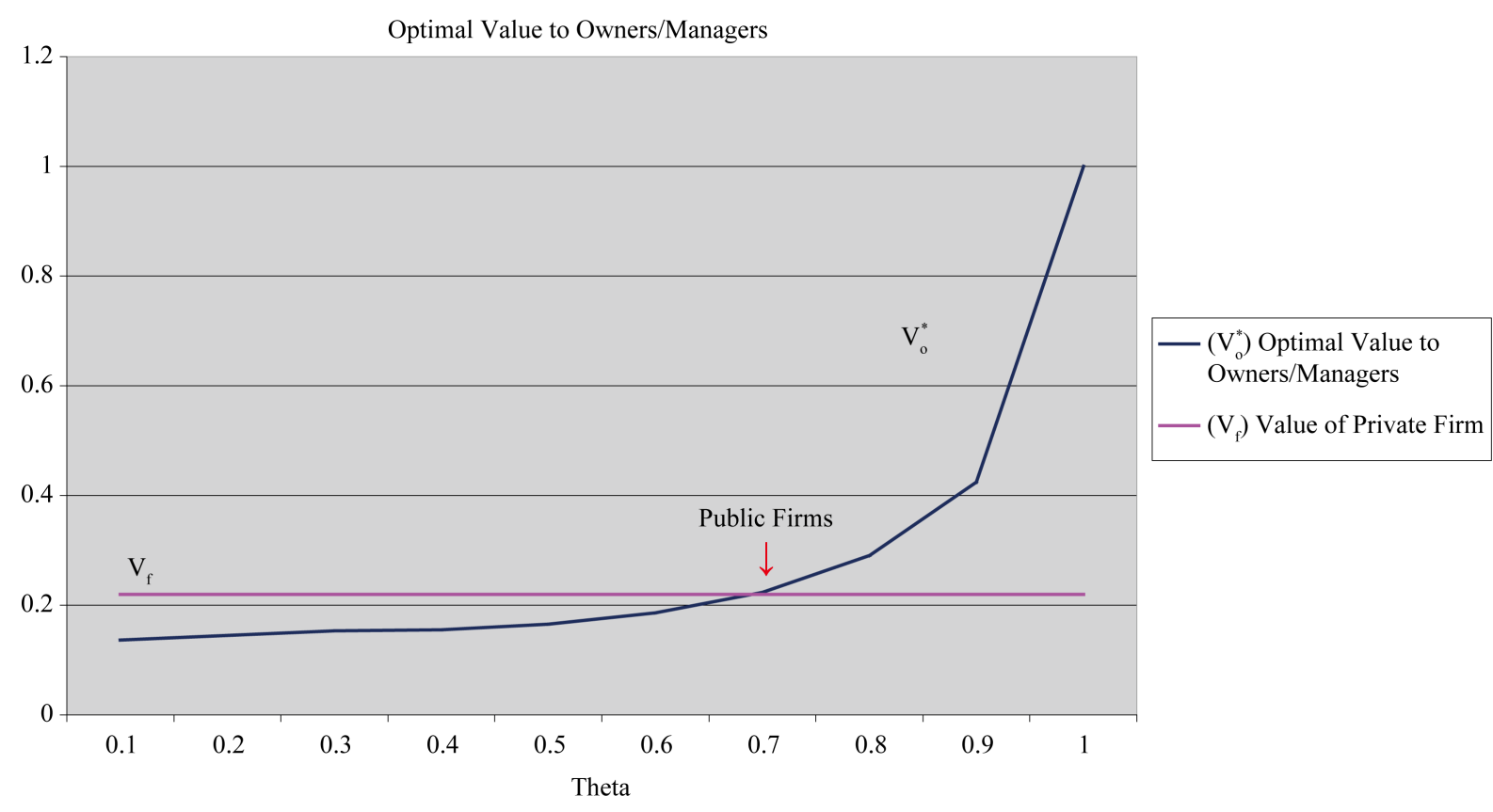

Figure 2. Optimal value to owners/managers where the partners compete in an asymmetric contest for control.

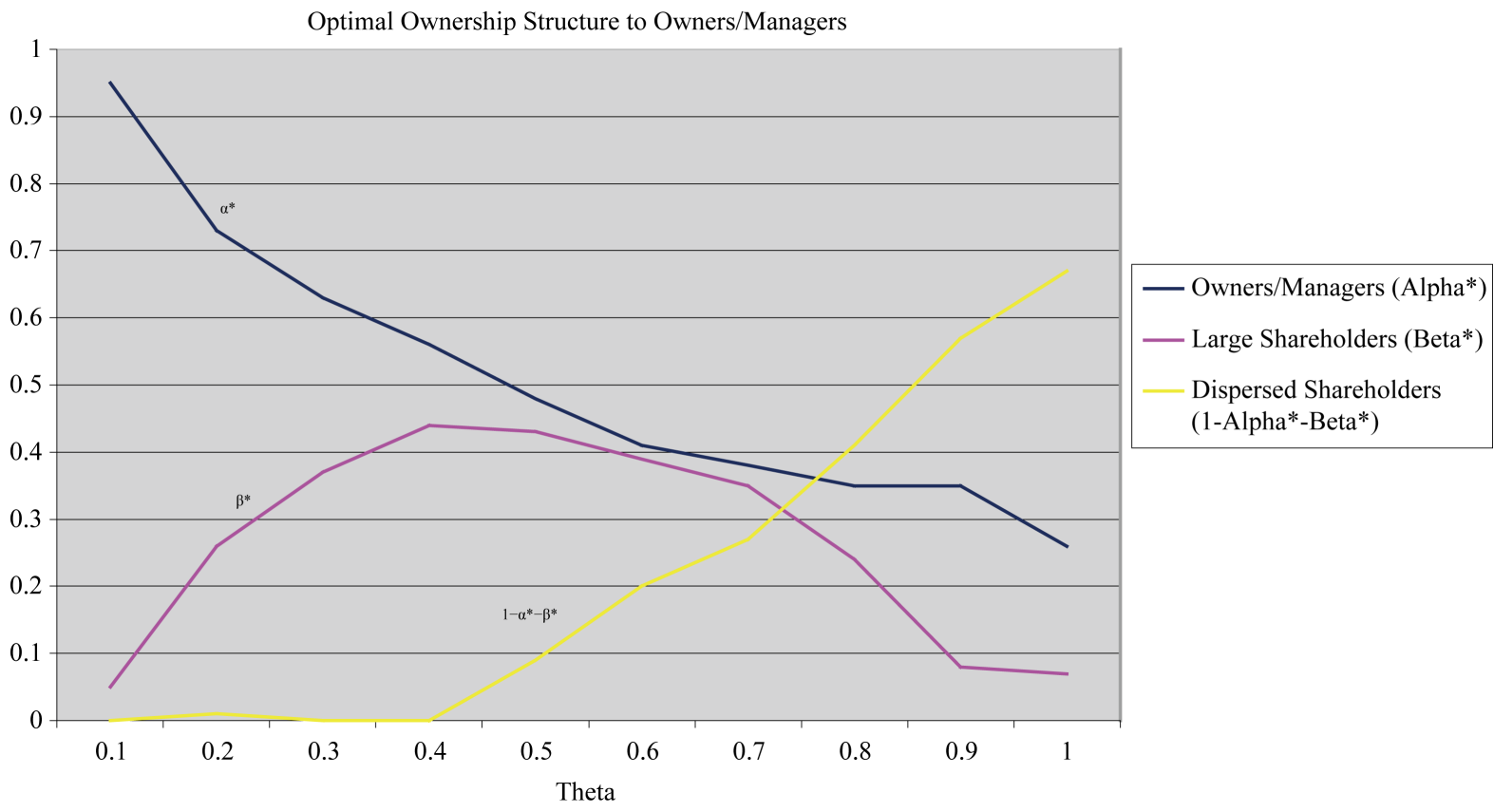

Figure 3. Optimal ownership structure to owners/managers where the partners compete in an asymmetric contest for control.

that the optimal ownership structure chosen by the entrepreneur generally involves some measure of dispersion (more than one external investor). It may also involve a certain degree of monitoring by a large external shareholder, because in order to obtain equity capital more cheaply, the initial owner needs to restrain his own future tendency to stray. So in legal regimes with intermediate investor protection (intermediate values of $\theta$ ), the optimal ownership structure chosen by entrepreneurs involves keeping the majority of firm ownership while selling the rest of the company shares to large shareholders. The family controlled firm emerges as the equilibrium outcome. 
When legal protection of outside investors is very good (high values of $\theta$ ), there is no need for monitoring in equilibrium, and the widely held professionally managed firm emerges as the equilibrium outcome.

Our results are consistent with Lopez-de-Silanes, Shleifer and Vishny [3], Shleifer and Wolfenzon [14] and Burkart, Panunzi and Shleifer [16] as we show that the concentration of ownership of shares in public companies is negatively related to the legal protection of outside shareholders. In contrast with Castillo and Skaperdas [2], we obtain a negative and monotone relationship between the legal protection of outside shareholders and the size of the ownership share retained by the owners/managers.

\section{Equilibrium Choices Where the Partners Compete with the Powers of Persuasion}

In stage three of the game, the competition between large shareholders and owners/managers involves owners/ managers and large shareholders devoting costly resources to influence the opinion of a third party: Board of Directors, Securities and Exchange Commission or the courts in their favor (Skaperdas and Vaidya [12]). Briefly, the functional form is derived using the following process: managers and large shareholders expend resources $e_{m}$ and $e_{l s}$ on gathering information and evidence. The evidence and information produced are presented to the Board of Directors, Securities and Exchange Commission or the courts. Based on the evidence and information presented, the Board of Directors, Securities and Exchange Commission or the courts make an inference about the truth. They update their prior beliefs in light of the evidence and information presented and the posterior beliefs thus produced determine the probability of their judgment being in favor or against the claimant.

In addition to the effect that resources have in collecting information and uncovering evidence, the efficiency of the judiciary and law enforcement system should have an effect on the ease or difficulty with which each side can collect information or uncover evidence in favor of its cause. In our analysis, the higher the efficiency of the judiciary and law enforcement system the easier it is for shareholders to collect information or uncover evidence in their favor and the harder it is for managers to collect information or uncover evidence in theirs.

As before, the share of the gross value of the public firm received by the owners/managers is a function of the two kinds of effort:

$$
p\left(e_{m}, e_{s}\right)=0.5-\phi\left[\theta e_{l s}^{\sigma}-(1-\theta) e_{m}^{\sigma}\right]
$$

with $e_{m}$ representing costly efforts exerted by the owners/managers to influence the opinion of the Board of Directors, Securities and Exchange Commission or the courts in their favor while $e_{l s}$ represents costly efforts exerted by large shareholders to influence the opinion of the Board of Directors, Securities and Exchange Commission or the courts in theirs. $1-p\left(e_{m}, e_{l s}\right)$ represents the share of the gross value of the public firm received by shareholders (including the owners/managers who keep a share of the firm).

$\theta$ represents the efficiency of the judiciary and law enforcement system in a country and it varies between 0 and 1. An increase in $\theta$ towards 1 would indicate stronger law enforcement or a more efficient legal system. Conversely a movement of $\theta$ toward 0 , would indicate weaker law enforcement or a less efficient legal system. The function $e^{\sigma}$ is positive, increasing and strictly concave. The parameter $\phi$ is taken as exogenous in our model and it varies between 0 and 0.5 . In a more fully articulated model, it would be an increasing function of the likelihood of conviction of the managers of the firm given that there is legal evidence against them.

\subsection{Solving for Equilibrium}

Large shareholders and owners/managers choose their equilibrium efforts simultaneously and in a manner that maximizes their total payoffs in stage three of the game. Given values of the owners/managers share in the public firm $(\alpha)$, large shareholders share $(\beta)$ and the value of the public firm to both large and dispersed shareholders $(S)$ we solve for the owners/managers equilibrium efforts by differentiating Equation (1) above with respect to $e_{m}$ and setting it equal to zero. The owners'/managers' equilibrium efforts are given by Equation (20) below:

$$
e_{m}^{*}=\left((1-\alpha)(1-\theta) \phi \sigma V_{p}\right)^{\left(\frac{1}{1-\sigma}\right)}
$$

In order to solve for large shareholders' equilibrium efforts, we differentiate Equation (3) above with respect to $e_{l s}$ and we set it equal to zero. Large shareholders' equilibrium efforts are given by Equation (21) below: 


$$
e_{l s}^{*}=\left(\beta \theta \phi \sigma V_{p}\right)^{\left(\frac{1}{1-\sigma}\right)}
$$

Substituting Equations (20) and (21) into Equations (1) and (2) above we get the equilibrium payoffs to the owners/managers and to shareholders respectively:

$$
\begin{aligned}
V_{m}^{*}= & V_{p}+0.5(\alpha-1) V_{p}+(\alpha-1)(\phi \theta)^{\left(\frac{1}{1-\sigma}\right)}(\beta \sigma)^{\left(\frac{\sigma}{1-\sigma}\right)} V_{p}^{\left(\frac{1}{1-\sigma}\right)} \\
+ & ((1-\alpha) \phi(1-\theta))^{\left(\frac{1}{1-\sigma}\right)}(\sigma)^{\left(\frac{\sigma}{1-\sigma}\right)} V_{p}^{\left(\frac{1}{1-\sigma}\right)}-((1-\alpha)(1-\theta) \phi \sigma)^{\left(\frac{1}{1-\sigma}\right)} V_{p}^{\left(\frac{1}{1-\sigma}\right)} \\
V_{s}^{*}= & 0.5(1-\alpha) V_{p}+(1-\alpha)(\phi \theta)^{\left(\frac{1}{1-\sigma}\right)}(\beta \sigma)^{\left(\frac{\sigma}{1-\sigma}\right)} V_{p}^{\left(\frac{1}{1-\sigma}\right)} \\
& -((1-\alpha) \phi(1-\theta))^{\left(\frac{1}{1-\sigma}\right)}(\sigma)^{\left(\frac{\sigma}{1-\sigma}\right)} V_{p}^{\left(\frac{1}{1-\sigma}\right)}-(\beta \theta \phi \sigma)^{\left(\frac{1}{1-\sigma}\right)} V_{p}^{\left(\frac{1}{1-\sigma}\right)}
\end{aligned}
$$

\subsection{Choosing the Optimal Ownership Structure to Owners/Managers}

Headings, or heads, are organizational devices that guide the reader through your paper. There are two types: component heads and text heads.

Owners/managers choose the proportion of shares to sell to large shareholders $(\beta)$, the proportion to keep $(\alpha)$, the proportion to sell to dispersed shareholders $(1-\alpha-\beta)$ and the fraction $(\gamma)$ of the equity sales proceeds to keep in a manner that maximizes their expected payoff from taking their company public.

$$
\operatorname{Max}_{\alpha, \beta, \gamma}\left(V_{m}^{*}(\alpha, \beta, \gamma S)+(1-\gamma) V_{s}^{*}(\alpha, \beta, \gamma)\right)
$$

Due to the complexity in solving the maximization problem above, we will illustrate by an example as shown below:

Example: we assume that that the value of the public firm is determined through a Cobb-Douglas-like form:

$$
V_{p}(\gamma S)=K(\gamma S)^{0.5} \text { where } K>0
$$

Substituting (25) into (23) above and in the special case of $\sigma=0.5$, we get:

$$
S=V_{s}^{*}(\alpha, \beta, \gamma S)=\frac{4(1-\alpha)^{2} K^{2} \gamma}{\left[4-2(1-\alpha) \beta \theta^{2} \phi^{2} K^{2} \gamma+2(1-\alpha)^{2} \phi^{2}(1-\theta)^{2} K^{2} \gamma+\beta^{2} \phi^{2} \theta^{2} K^{2} \gamma\right]^{2}}
$$

To determine the optimal share to sell to large shareholders $\beta^{*}$, the optimal share to owners/managers $\alpha^{*}$ and the optimal share to sell to dispersed shareholders $(1-\alpha-\beta)^{*}$, we plug in (25) and (26) into the maximization problem (24) above. Due to the difficulty in obtaining an explicit solution, I have solved the maximization problem using a numerical investigation as shown in Figure 4 and Figure 5 attached. Numerical solution results show the optimal ownership structure that maximizes the expected payoff to owners/managers for the different values of $\theta$ (efficiency of the judiciary and law enforcement system) and are discussed in the sections below.

The choice of the constant $K$ depends in part on the value of $\phi$ and both values of $\phi$ and $K$ should be chosen in a manner that would be consistent with what is observed in the real world. For our analysis we have chosen $K$ to equal 20 and $\phi$ to equal 0.25 . Future work need to be done to get an empirical estimation for both $K$ and $\phi$.

\subsection{Analysis of Figure 4 Below}

In our model, we have assumed that the legal protection of outside shareholders complements the efforts exerted by large shareholders in monitoring the managers, so as the efficiency of the judiciary and law enforcement system improves $(\theta \uparrow)$, equity valuation by outside shareholders increase and the value of public firms increase. Results obtained from our numerical solution are consistent with the existing literature as we show that as the efficiency of the judiciary and law enforcement system improves $(\theta \uparrow)$, the optimal value to the owners/managers from taking their firm public increases and the likelihood that entrepreneurs will take their privately held 


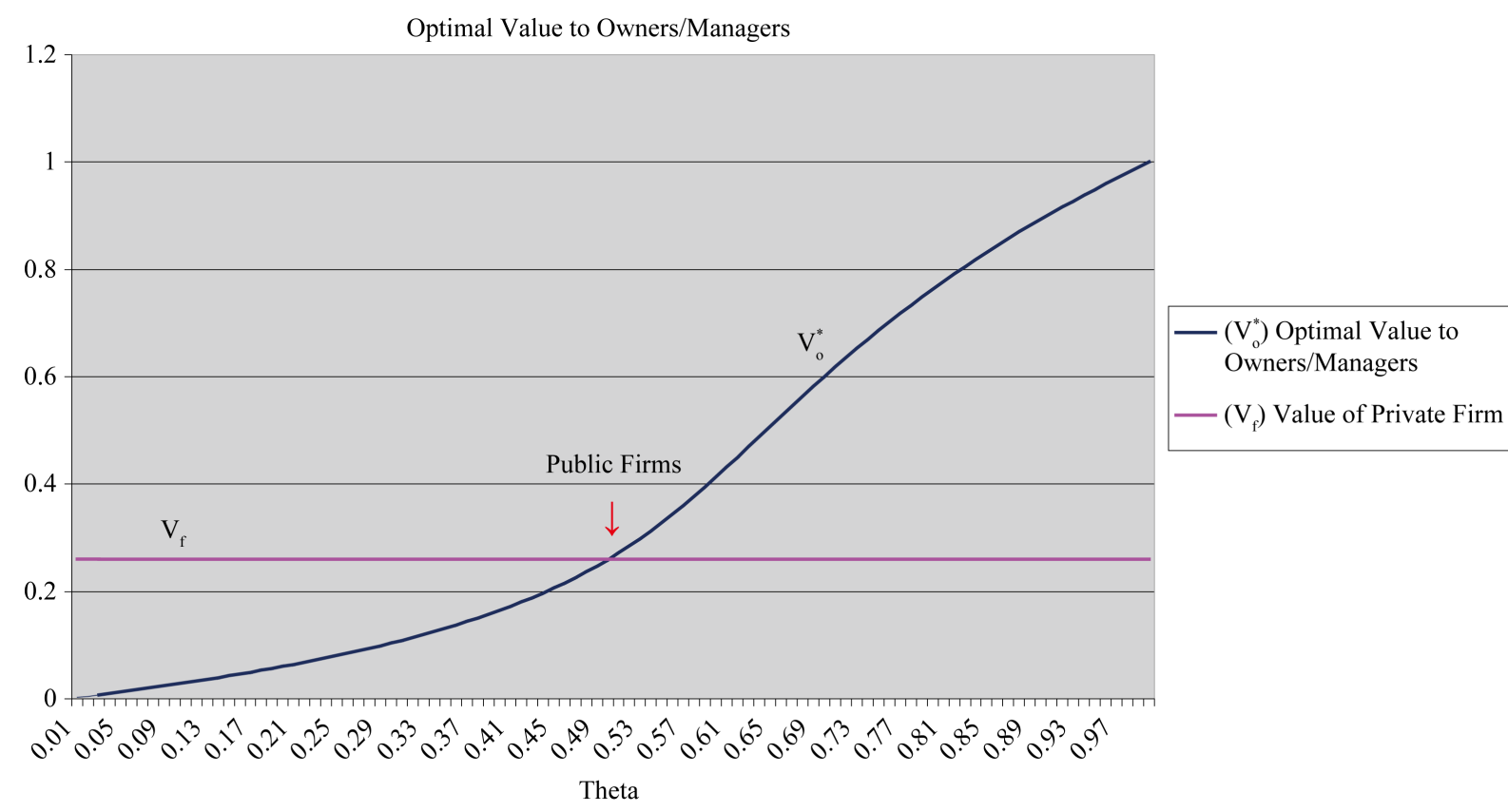

Figure 4. Optimal value to owners/managers where the partners compete with the powers of persuasion.

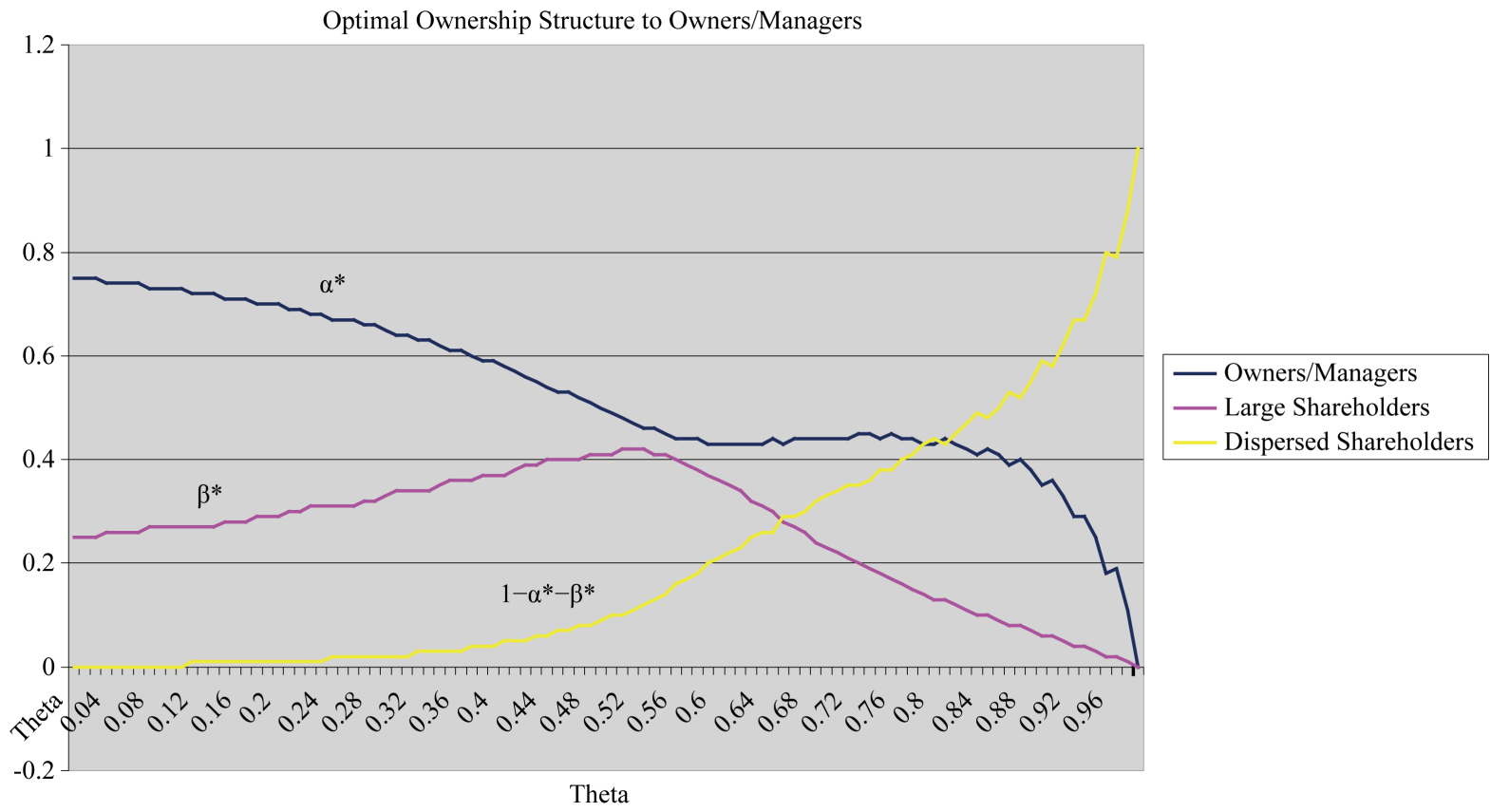

Figure 5. Optimal ownership structure to owners/managers where the partners compete with the powers of persuasion.

firms public increases. An example with $V_{f}{ }^{3}$ as the market value of the private firm and $V_{O}^{*}$ being the optimal value to the owners/managers from taking their firm public is shown in Figure 4 attached.

\subsection{Analysis of Figure 5 Below}

Numerical solution results show that owners/managers get a higher return from investing an additional dollar in the public firm than they would from retaining it (except for investing in the public firm, we assume that the

${ }^{3}$ The value of the private firm is exogenously determined in our model. 
owners/managers earn zero return on their money), so they reinvest the full amount of the equity sale proceeds back into the public firm $\left(\gamma^{*}=1\right)$.

Upon deciding to take their privately held company public, the owners/managers have to find the particular combination of concentrated and dispersed ownership that maximizes their wealth. Three sources of value contribute to the owners/managers payoff: expropriating part of the value of the public firm; retaining part of the proceeds received from selling equity; and the value received from being shareholders.

In legal regimes with weakest shareholder protection, relatively low values of $\theta$, the value of the private firm exceeds its value being public (Figure 4) and the original owners decide against taking their privately held firm public. Ownership stays with the original founders and the family owned corporation emerges as the equilibrium outcome.

In legal regimes with intermediate shareholder protection, values of $\theta$ midway between 0 and 1 , the value of the public firm exceeds its value being private (Figure 4) and the original owners decide to take their privately held firm public. Majority ownership stays with the original founders and the family controlled corporation emerges as the equilibrium outcome $\left(\alpha^{*}>0.5\right)$.

\section{Concluding Remarks}

Our results are consistent to a large extent with the existing literature on Corporate Governance as Burkart, Panunzi and Shleifer [16] and Shleifer and Wolfenzon [14] show that firms are more valuable, shareholder expropriation is lower and ownership concentration is lower, with better protection of shareholders. Our results are also consistent with Burkart, Panunzi and Shleifer [16] as they show that in legal regimes that successfully limit the expropriation of minority shareholders, the professionally managed corporation widely held emerges as the equilibrium outcome. In legal regimes with intermediate protection, management is delegated to a professional, but the family stays on as large shareholders to monitor the manager. In legal regimes with the weakest protection, the founder designates his heir to manage and ownership remains inside the family. In Western Europe for example, many publicly traded firms are family controlled through a majority ownership while in emerging markets such as the Middle East, both ownership and control tend to stay with the family. In the United States, separation of ownership and control occurs at an early stage where the original founder and his family retain only marginal ownership.

Even though our findings are consistent to a large extent with the existing empirical literature, measuring the correct level of legal protection of outside shareholders $(\theta)$ for different countries would be vital in interpreting empirical results. Conflicts between shareholders and managers are not the only situations where agency costs are incurred. We can think of the company's overall value as a pie that is divided among a number of claimants. These include management, shareholders, company workforce, banks, creditors and the government. Work is currently underway to analyze the situation where the owners raise cash from both equity and debt financing to fund the firm's investment decisions.

\section{Acknowledgements}

I gratefully acknowledge the support of The Lebanese American University, without which the present study could not have been completed.

\section{References}

[1] La Porta, R., de Silanes, F.L., Shleifer, A. and Vishny, R. (2000) Investor Protection and Corporate Governance. Journal of Financial Economics, 58, 3-27. http://dx.doi.org/10.1016/S0304-405X(00)00065-9

[2] Ramon, C. and Skaperdas, S. (2005) All in the Family or Public? Law and Appropriative Costs as Determinants of Ownership Structure. Economics of Governance, 6, 93-104. http://dx.doi.org/10.1007/s10101-005-0103-4

[3] La Porta, R., de Silanes, F.L., Shleifer, A. and Vishny, R. (1998) Law and Finance. Journal of Political Economy, 106, 1113-1155. http://dx.doi.org/10.1086/250042

[4] Shleifer, A. and Vishny, R. (1986) Large Shareholders and Corporate Control. Journal of Political Economy, 94, 461488. http://dx.doi.org/10.1086/261385

[5] Jensen, M. and Meckling, W. (1976) Theory of the Firm: Managerial Behavior, Agency Costs and Ownership Structure. Journal of Financial Economics, 3, 305-360. http://dx.doi.org/10.1016/0304-405X(76)90026-X 
[6] Grossman, S. and Hart, O. (1980) Takeover Bids, the Free-Rider Problem, and the Theory of the Corporation. Bell Journal of Economics, 11, 42-64. http://dx.doi.org/10.2307/3003400

[7] Mike, B. and Panunzi, F. (2006) Agency Conflicts, Ownership Concentration, and Legal Shareholder Protection. Journal of Financial Intermediation, 15, 1-31. http://dx.doi.org/10.1016/j.jfi.2004.12.004

[8] Skaperdas, S. (1996) Contest Success Functions. Economic Theory, 7, 283-290. http://dx.doi.org/10.1007/BF01213906

[9] Anderton, C. (2001) Conflict Economics in Christian Perspective. Faith \& Economics, 37, 1-9.

[10] Hirshleifer, J. (1995) Theorizing about Conflict. In: Hartley, K. and Sandler, T., Eds., Handbook of Defense Economics, Elsevier, Amsterdam. http://dx.doi.org/10.1016/S1574-0013(05)80009-2

[11] Derek, C. and Riis, C. (1997) Contest Success Functions: An Extension. Economic Theory, 11, 201-204.

[12] Skaperdas, S. and Vaidya, S. (2012) Persuasion as a Contest. Economic Theory, 51, 465-486. http://dx.doi.org/10.1007/s00199-009-0497-2

[13] La Porta, R., De Silanes, F.L., Shleifer, A. and Vishny, R. (1997) Legal Determinants of External Finance. Journal of Finance, 52, 1131-1150. http://dx.doi.org/10.1111/j.1540-6261.1997.tb02727.x

[14] Shleifer, A. and Wolfenson, D. (2002) Investor Protection and Equity Markets. Journal of Financial Economics, 66, 3-27. http://dx.doi.org/10.1016/S0304-405X(02)00149-6

[15] Pagano, M. and Röell, A. (1998) The Choice of Stock Ownership Structure: Agency Costs, Monitoring and the Decision to Go Public. Quarterly Journal of Economics, 113, 187-225. http://dx.doi.org/10.1162/003355398555568

[16] Mike, B., Panunzi, F. and Shleifer, A. (2003) Family Firms. Journal of Finance, 58, 2167-2202. http://dx.doi.org/10.1111/1540-6261.00601

[17] Tullock, G. (1980) Efficient Rent Seeking. In: Buchanan, J., Tollison, R. and Tullock, G., Eds., Toward a Theory of Rent Seeking Society, Texas A and M University Press, College Station, 97-112.

[18] Zingales, L. (1995) Insider Ownership and the Decision to Go Public. The Review of Economic Studies, 62, 425-448. http://dx.doi.org/10.2307/2298036

[19] Ritter, J. (1987) The Costs of Going Public. Journal of Financial Economics, 19, 269-281. http://dx.doi.org/10.1016/0304-405X(87)90005-5

[20] Holmstrom, B. and Tirole, J. (1993) Market Liquidity and Performance Monitoring. Journal of Political Economy, 101, 678. http://dx.doi.org/10.1086/261893

[21] Hall, R. and Jones, C. (1997) Levels of Economic Activity across Countries. American Economic Review, 87, $173-177$. 